\title{
Rethinking Mindscapes and Symbols of Patriarchy in the Workforce to Explain Gendered Privileges and Rewards
}

\author{
Ladislaus M. Semali ${ }^{1} \&$ Elizabeth S. Shakespeare ${ }^{1}$ \\ ${ }^{1}$ College of Education, Pennsylvania State University, University Park, PA, USA \\ Correspondence: Ladislaus M. Semali, College of Education, 307 Keller Building, Pennsylvania State University, \\ University Park, 16802 PA, USA. Tel: 814-865-2246. E-mail: 1ms11@psu.edu
}

Received: November 11, 2013 Accepted: December 13, 2013 Online Published: January 20, 2014

doi:10.5539/ies.v7n2p37

URL: http://dx.doi.org/10.5539/ies.v7n2p37

\begin{abstract}
In this article the authors contend that gender inequalities in occupational divisions of labor are better understood in reference to the concept of symbolic patriarchy. The conceptual framework is informed by social constructionist theories that view gender not merely in light of sexual or biological differences but as interwoven, fluid, and contesting boundaries of authority. The goal here is to locate the labyrinths of power and unequal treatment of women, evidenced through the "gender pay gap" and derived from the social landscapes and mindscapes of inequality. The study concludes that workforce-based privileges and rewards for men seem to be sustained and reinforced by patriarchal socio-cultural systems of inequality and domination that maintain visible and invisible mechanisms of power, privilege and influence in symbolic, figurative, and metaphoric cultural forms, rendering them the norm.
\end{abstract}

Keywords: symbolic patriarchy, gendered privileges, feminized labor, masculinity, intersectionality

\section{Introduction}

Even though women in the workforce earning wages or a salary are part of an established modern phenomenon, many of the biggest workplace challenges facing working women worldwide orbit around "gender" (Butler, 1997). Specifically, gender inequality in the workplace presents women with stubbornly persistent challenges with respect to scale and form of employment and remuneration. To shed light on the quandary of privilege and rewards among working women and examine links between symbolic patriarchy and gendered privileges, this study situates differences between the sexes within "gender" discourse (Butler, 1993; Sunderland, 2004; Tannen, 1994) in order to better understand the ways in which gender inequality and patriarchal ideologies in a given society are perpetuated within historical periods. We asked: How do "gender pay gap" and "rewards" infringements manifest socially, culturally, and politically in the workplace? In this study, rewards refer to "a sum of money or other compensation offered to the public in general, or to a class of persons, for the performance of a special service" (Phelps \& Lehman, 2005).

A look at gender discourse considers "masculinity" or the symbols of manhood as socially produced subject positions while the rewards derived from this status indicate the ways in which male-constructed stereotypes discriminate against women by giving them less pay than men for equal work. Symbols of patriarchy include objects, people, and events in the so-called "gendered world" (Wood, 2001), serving to classify and organize the world into meaningful categories. But symbols of patriarchy can also reference imaginary things and fantasy worlds, or abstract ideas that are not in any obvious sense part of our material world (Johnson, 2001).

We argue that gender inequalities in occupational divisions of labor will be best understood in reference to the concept of symbolic patriarchy, which shifts from the dichotomized vision of gendered individuals of women and men, and instead focuses on the intra-familial power relations of father or oldest male as "symbolic fathers" and "father figures" (Gordon \& Hunter, 1998). By extension, the term symbolic patriarchy also refers to a system of government by males, and to the dominance of men in social or cultural systems (Meade \& Haag, 1998). In this way, patriarchy imposes masculinity and femininity character stereotypes in society, which strengthen unfair power relations between men and women. Imposing male-dominated stereotypes illustrates the mental frames of metaphoric structures and the deep-seated psyche of mindscapes that pervade the symbolisms of gendered patriarchal privilege and its influence on the social order. However, for the purposes of this study, the concept of patriarchy was useful precisely because it kept the gaze directed toward social relations rather 
than individual men or fathers who are motivated to dominate (Stern, 1998).

We recognize the complexity of the historical nature of patriarchy and realize that patriarchies have a number of interrelated dimensions that vary across time, place, material contexts and borders. These varieties are constantly shifting as power relations change in concert with other key changes (Hunnicutt, 2009; Patil, 2013). As referenced here, symbolic patriarchy opens up spaces to examine privilege and benefit infringements in normalized places (outside individual men and women) that sometimes benefits one gender and estranges the other, and other times happens in the form of "patriarchal bargain" as in the case of submissiveness in exchange for protection (Kandiyoti, 1988).

\section{Explanation of Inequality in Feminized Work}

In this article we present preliminary findings from a larger study of the historical links between symbolic patriarchy and gendered privileges in the U.S. Appalachian region. As a region nested within mountain ranges of the Eastern United States, Appalachia was purposely selected for this case study to shed light on the question, why do disparities in pay between the sexes persist? The region offers characteristics that reveal similarities with the rest of the U.S. and yet stark divergences exist in their poverty levels and the influences of symbolic patriarchy on working women. The authors of this study postulate that because parts of this region insist on agriculture and rural life with religion and family structure at the core of their livelihoods, regional comparisons might broaden the understanding of gendered privilege.

This case study collected evidence from secondary data sources including literature and films popular in the region as well as from Institute for Women's Policy Research (IWPR), Office of the State Controller, and the Appalachia Women's Fund to analyze symbolic patriarchy and gendered mindscapes in comparative perspective.

A study of symbolic patriarchy in the Appalachian region is part of a global phenomenon of male dominance that permeates all social interactions and insertions of every sphere of society (Momanyi, 2007; Walby, 2002). In many ways, workplace organization and the domestic division of labor retain the imprint of masculinity via a breadwinner society, presenting a challenge to gender equity within employment and in society as a whole (Valian, 1999). Even though feminists at both sides of the debates (e.g., Eisenstein, 1979; Jaggar \& Rothenberg, 1983; Mandell, 1995; Mitchell, 1975) postulate that the "gender gap" is a myth (see, e.g., Covert, 2012; Thompson, 2013) and despite civil rights laws passed in the U.S., gender inequities seem to persist and the debates rage on.

\subsection{Debates, Policy and Legislation of Feminized Work}

Historically, the formal labor market has been overwhelmingly filled with men. However, in the past century, and especially the last 50 years, increasing numbers of women have been entering the labor market throughout the world (Schaefer, 2008; World Bank, 2006). These women have diverse lives and cultures but share some fundamental experiences as women working for pay, despite many geographic and economic divides.

Gender inequality disputes and court challenges seem to be eclipsed by identity-based claims raising issues relating to race, ethnicity, gender, sexual orientation, and disability. Years after the Civil Rights Act of 1964 and the Disability Act of 1990, antidiscrimination laws reify and reinforce gender, ethnicity, race, sexual orientation, and disability consciousness in workers. Civil rights lawyers and adult educators, among other progressive social change agents, have actively taken up these causes (Crain \& Matheny, 2001). For example, in 2012, civil rights violations were cited against Target, FedEx, Wal-Mart, and the City of Corpus Christi, Texas (Levine, 2012). These cases called for investigations to determine the reasons for persistent pay disparities in the social conditions of working women and how such disparities might be linked to gendered privileges and gender pay gaps.

Title VII of the 1964 Civil Rights Act forbids sex-based discrimination in any aspect of employment, including hiring, firing, pay, job assignments, promotions, layoffs, training, fringe benefits and any other terms or conditions of employment. Sex-based discrimination involves treating an employee or job applicant unfavorably (e.g., in pay) based on that person's sex (Civil Rights Act, 1964). When one gender is favored over another in the workforce, it is "gendered privilege" (Connell, 2002).

\subsection{Women's Work in Global Markets}

Globalization and industrialization are two factors that explain the increased presence of women in workplaces. Yet, even as women continue to participate in the labor market in larger numbers globally, the type of work they do and how it fits into their lives still differs from the type of work men do. Women's choices about work depend on national, local, cultural, religious, and personal factors. Different areas of the world show varied rates of labor. For example, while in the Middle East and North Africa about 30\% of the women work, in Latin 
America, Europe, Central Asia, and sub-Saharan Africa, closer to $60 \%$ of the women work. In the United States and East Asia, participation is even higher-around 70\% (World Bank, 2006).

Women's participation in the U.S. labor force climbed during the 1970 s and 1980 s, reaching $60 \%$ in 2000 . In 2010, American women on average earned $81 \%$ of what their male counterparts earned (Bureau of Labor Statistics, 2010; U.S. Department of Labor, 2011). However, in 2010 this figure declined to $46.7 \%$ and is not expected to increase by 2018 (U.S. Department of Labor, 2011) due to the Great Recession of 2007-2010, which affected men and women differently but affected women more adversely. One in five women is working part-time because they cannot find full-time work, while at the start of the recession, fewer than one in ten women were doing so (DPE, 2011).

Women have made big strides during the last few decades by moving into jobs and occupations previously done almost exclusively by men, yet during the last decade there has been very little further progress in the gender integration of work. It is generally suggested that the wage gap exists for various reasons, such as differences in the types of positions held by men and women, differences in the pay for jobs men typically go into as opposed to women, differences in amount of work experience, and breaks in employment (U.S. Department of Labor, 2009). The real gap isn't between men and women doing the same job. It's the different jobs that men and women take (Thompson, 2013).

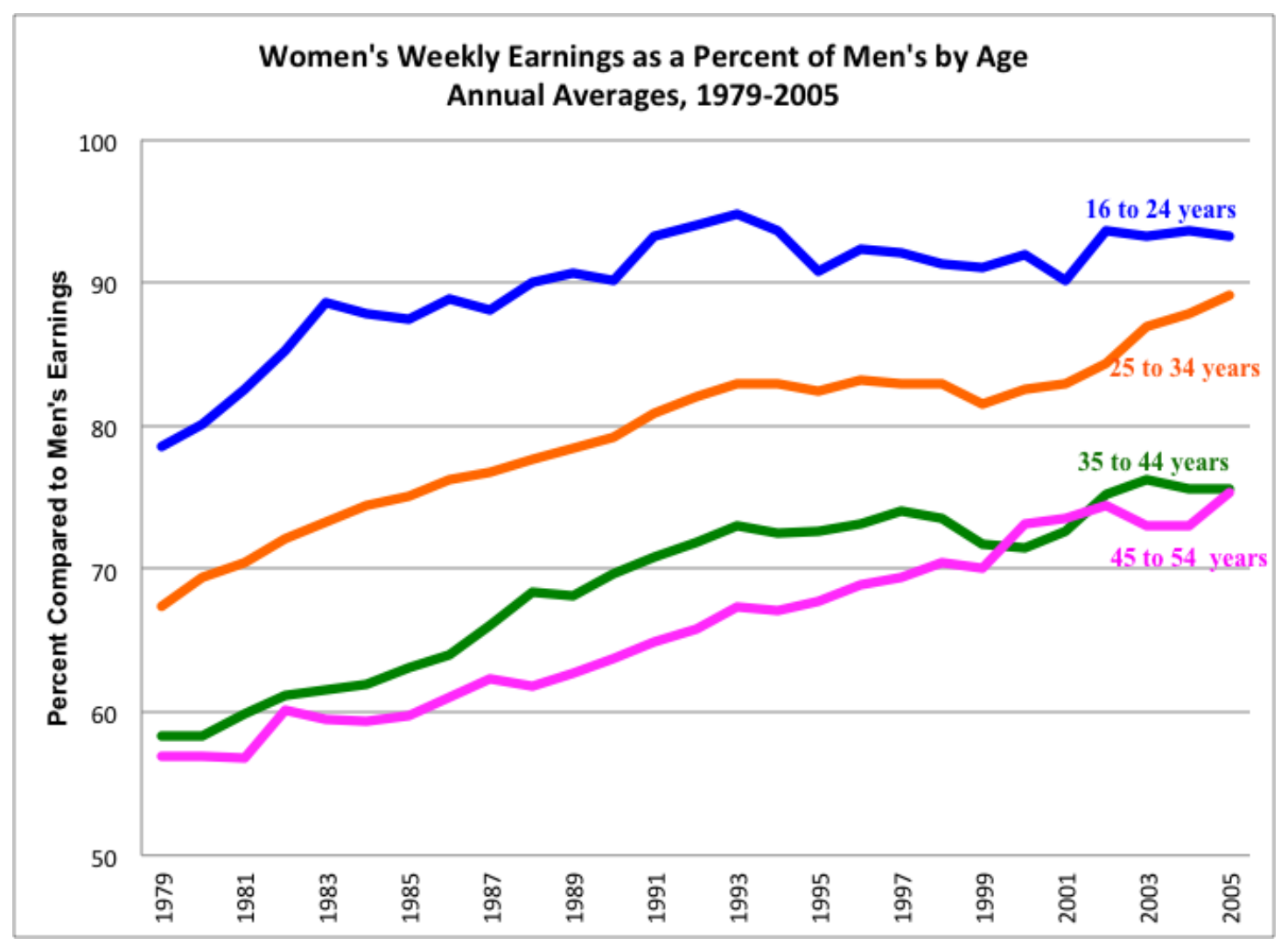

Figure 1. Annual averages of women's weekly earnings as percentage of men's by age

Source: The Institute for Women's Policy Research (IWPR) Database, 2012.

Thus, persistent occupational segregation is a significant contributor to the lack of progress in closing the gender-based wage gap, which exists for two main reasons: discrimination and segregation. Since gender is one of the primary means by which people categorize other humans, it is one of the most common bases on which people discriminate or treat others unequally. Social scientists view gender as socially constructed; that is, the distinctions and judgments that people make based on gender are a product of their beliefs and understandings and those of their societies (Butler, 1999; Lorber, 1994; West \& Zimmerman, 1987).

Labor market-based discrimination occurs when women are discouraged from seeking certain types of jobs or 
are not hired for jobs due to their gender. Gender inequality is a result of the persistent discrimination experienced by one group of people based upon gender and manifests differently according to race, culture, politics, country, and economic situation (Neumark, 1993). It is considered a causal factor of violence against women (Hunnicutt, 2009).

The glass ceiling effect suggests that gender provides significant disadvantages toward the top of job hierarchies and becomes worse over the course of a person's career. The term implies that invisible or artificial barriers prevent women from advancing within their jobs or receiving promotions (Bell et al., 2002). These barriers exist despite achievements or qualifications and when controlling for other characteristics that are job-relevant such as experience, education, and abilities. The inequality effects of the glass ceiling are more prevalent within higher-powered or higher-income occupations, with fewer women holding these types of occupations. The glass ceiling effect also indicates Women's limited opportunities for income raises and promotion or advancement to more prestigious positions or jobs (Arulampalam et al., 2007; Blau \& Kahn, 2001; Khanna, 2012).

\section{3. "Gender Discourse" as Alternative Explanation of Wage Pay Gap}

In this section we turn to qualitative studies that use gender discourse to explain symbols of patriarchy as an alternative reason for the persistence of gender inequality in the workplace. Feminist studies have identified the relationship between patriarchy and gender as crucial to Women's subordinate position (Barret \& McIntosh, 1980; Bhasin, 1993; Chitnis, 2004; Lerner, 1986; Walby, 1986). Until recently, gender discourse has involved a range of feminist viewpoints appearing in copious writings on discrimination and the exploitation of Women's labor/less pay than men for equal work (Hanmer, 1990; Lorber, 1994). Hanmer examined men's individual and collective expressions of power in interpersonal relations, groups, and social institutions known as gendered privilege, and how the social exploitation of women coalesces into inequalities between the sexes that seem natural and therefore are taken for granted.

The overarching assumption of a gendered privilege study stems from a theory of privilege that postulates that male privilege and heterosexual privilege result from "gender hierarchy" (Hartmann, 1976). In other words, one gender is valued over another based on an unequal male order. Equally, the power to ignore "gender" when the sexes are about gender is a privilege. In effect, those who are socially privileged are rarely explicitly self-conscious of the nature of their privilege or willing to examine their privilege because they see their state as "natural and normal." It is a societal advantage because privilege is realized by setting apart those "who are in" from those "who are out;" those "who belong" to masculinity and those "who don't" (Johnson, 1997).

To develop theories that explain how gender inequalities are rooted in the ideologies of gender difference and hierarchical gender order, feminist theorists expounded and continue to challenge gender inequality and the gendered division of labor in the private and social (public) spheres (Habermas, 1991; Ray, 2010; Seidman, 1994). Take note that the use of this nomenclature, "feminists theorists," does not imply that all feminists belong to a homogeneous group, or necessarily are all women. We recognize there are different varieties of feminist perspectives including: perspectives from Liberal Feminists, Marxist Feminists, Socialist Feminists, Radical Feminists, Eco-Feminists, Postmodern Feminists, Black Feminists, Lesbian Feminists, and so on.

For example, feminists have taken up widespread critiques around sociological terms such as male-dominated society (Knoppers, 1993), sexual inequality theory (Martin, 1994) and the frequently referenced feminist (theory) perspectives (Chodorow, 1978; Firestone, 1978; Millet, 1977; Smiley, 2004; Walby, 1986, 1989). In radical feminism, the patriarchal family is viewed as a major institution whose role is to foster gender inequality through the socialization of children and subordinate women by forcing them to conform to feminine stereotypes (Greer, 2008).

\section{Cultural (Re)production of Masculinity in "Gender" Discourse}

In taking up the "gender pay gap" as a dynamic of inequality and as a symptomatic problem or indicator of gendered privilege, the authors recognize the complexity of the issues involved in such an analysis. To make sense of this complexity, the present study is informed by Bacchi's (1999) model of gender discourse analysis to understand the premises underlying the ways of tackling gender issues. Here, discourse is the way in which language is used socially to convey broad historical meanings (Henry \& Tator, 2002). Discourse language is identified by the social conditions of its use, by who is using it and under what conditions. Broadly, gender discourses may be understood as the generally accepted and authorized ways of speaking or writing about or understanding gender (Christensen \& Ferree, 2008).

In the present study, gender discourses imply the ways of talking about policy, affirmative action, and the law, including frequent congressional debates on which gender mainstreaming is based and eventually assumed to 
steer workplace politics in a certain direction. A discourse analysis approach is important because it draws attention to examine and make sense of historical meanings (Wodak \& Meyer, 2009). It points to what may be regarded as a problem (e.g., gendered privilege), why it is a problem, how it is explained, what is thought to be its cause, what solutions are considered suitable, and who is responsible for solving the problem. Bacchi (1999, p. $25)$ identified three analytical categories for investigating such a problem: (1) questions aimed at the groups to which values and positions are attributed (e.g., people at a disadvantage or in need), (2) questions aimed at revealing what can be said, when and where it can be said, and by whom, (3) questions aimed at the lived effects, namely, the impact on people's lives.

Informed by tenets and perspectives from social constructionism, discourse analysis, semiotics of gender, the sociology of social problems, and feminist perspectives, the analysis of gendered privilege reveals some visible and invisible mechanisms of power, privilege, and influence in symbolic, figurative, and metaphoric cultural forms that represent and render gendered privileges to be taken for granted. Next, we offer some rationales for these perspectives.

Constructionist theories propose a complex and mediated relationship between things in the world, for example, our concepts in thought and language (Hall, 1997). The assumption is that meanings prevalent in our culture that we take for granted tend to form a set of interconnections between language and linguistic codes or conventions to produce meaning. Hall pointed out that to understand the dominant discourses in contemporary United States, for example, one needs to pay attention to its current multi-discursive and multicultural nature - therefore, any analysis of its culture must be concerned with its discursive practices.

According to Foucault (1980, p. 145), discourses do not simply reflect "reality" or innocently designate objects. Rather, they constitute objects in specific contexts according to particular relations of power. In other words, to understand "gendered privilege" or any other topic or event, one must uncover the knowledge/power nexus and "the process of discursive contestation by which powerful discourses (or dominant ideology) work to repress, marginalize, and invalidate others, by which less powerful ones struggle for audibility (voice) and for access to the technologies of social circulation and by which they fight to promote and defend the interests of their respective social formation".

The discourse of gender advances the interests of males and has an identifiable repertoire of words, images, and practices through which masculine power is applied. It is important therefore to remember, as Hall (1997) has pointed out, that the repertoire or articulation of positions of what is valued (male labor) and not valued (feminized labor) is always a terrain of struggle, noting that the dominant discourses, those that occupy the mainstream, serve dominant social interests, for they are products of history that has secured their domination (see also Semali, 2000, pp. 105-107).

We therefore argue that patriarchal discourses have a tendency to socially construct masculinity and manhood through a historical process that is likely to sustain gender practices through a hegemonic symbolic order that becomes sanctioned by male ideologies and a patriarchal social structure dominated by masculinity and the male ego. Clearly, the question that this study poses - why does gender inequality persist among the sexes-finds a partial answer in this proposition and needs to be examined from the perspective of "hegemonic symbolic order."

As pointed out by Momanyi (2007, p. 25), (and we concur) that "masculinity" needs to be analyzed as a phenomenon positioned by the semiotics of gender discourse within the power processes that produce subject positions which direct person's thoughts and actions to construct gendered privilege. Momanyi insisted that subject positions are usually created through a historical process that sustains gender practices, which are in turn controlled by a hegemonic symbolic order "justified" and sanctioned by "male ideologies of superiority". Equally, this viewpoint confirms what Figes (1978, p. 23) clearly stated: that men continue to perpetuate the idea that women are intellectually inferior (or not fit for certain jobs) so as to boost their own feeling of superiority. Such ideology, though troubling, has pervaded messages and meanings of inequality in cultural socializations of boys and girls throughout history in both developing and advanced nations.

In turn, cultural (re)production theories (Bourdieu, 1977) also can help to explain gendered privilege by providing insights and links with masculinity and how masculinity is historically produced to subordinate women. Cultural (re)production refers to the ways in which the ruling ideas of a social system are related to structures of class production and power, and how these are legitimated and perpetuated in a society (Eder \& Parker, 1987). For example, people make references to "real men" and about being macho, usually in purely sexual sense, but not always (e.g., the commonly used idiom "to have balls," meaning men's valor, to be brave or the ultimate dare from which a man cannot back down without incurring more loss of dignity).

The topic of manliness often crops up in casual conversations as well as in discussions in schools. The "real man" 
phenomenon is part of the everyday lexicon found in most societies, even in most unlikely places like the Rambo films or figurines like G.I. Joe toys. The language, metaphors, and images that reify masculinity are pervasive in society. What is often overlooked is that they frequently coalesce to (re)produce ways of thinking about Women's subordinate position, which in turn produces the notion that their labor is less valuable than men's. It seems natural, for example, to see men as doctors, pilots, presidents, CEOs and school principals and men are not likely to contest this "natural" order.

Likewise, Anderson-Levitt (2003) described how teachers and parents alike, (regardless of their class position and for rather different reasons) come to endorse, and thus reproduce, the dominant construction of schooling, including gender roles and gender expectations. Actually, gender is one of the primary aspects of identity that we learn through conversations with others. In the U.S., gender is extremely important and is tied to the social order of a whole society (Fox-Genovese, 1991). Research has shown that views on gender are communicated by parents through responses to children (Chodorow, 1989), through play activities with peers (Malts \& Borker, 1982), and through teachers' interactions with students (Wood, 1991).

The intensity of focus on gender may explain why children develop this as one of their first clear senses of self. Before they know their nationality, religion, or social status, most children develop gender constancy and see themselves as gendered beings (Wood, 1991). These cultural forms and practices tend to support masculinity to form a kind of capital that "represents ways of talking, acting, and socializing, as well as language practices, values, and types of dress and behavior" (McLaren, 1999, p. 219).

Cultural perspectives on gender also inform us about the intricacies of gender arrangements within our own society. Mead (1934) developed a broad theory, which postulated that individuals learn to participate completely in their society and to share values through communication (symbolic interaction) with others. He concluded that communication is the central process through which we gain a sense of who we are. Mead's symbolic interaction theory covers socialization in general and can be applied specifically to how we learn gender through interactions with others.

With each label people offer the child a self-image, and in turn, the child internalizes other peoples' views (concepts) to arrive at his/her own understanding of whom they are. This kind of meaningful category or "mindscape," so internalized, becomes reproduced every time a gender reference is made. Thus, mindscapes become mental processes, categories, or frames of mind that create or derive a particular worldview or ideology (Carney, 2008). In fact, from the moment of birth, persons engage in interactions with others, especially parents, who tell us who we are, what is appropriate for us, and what is unacceptable, collectively forming messages in our minds that become the frame of mind or database that "reproduces" future mindscapes.

\subsection{Mindscapes of Cultural Reproduction}

Cultural (re)production theories therefore emphasize the (re)production of the structure of power relations and symbolic relationships in society by contributing to the reproduction of cultural capital among classes. Bourdieu (1977, p. 490) saw cultural capital as being, "the general cultural background, knowledge, disposition, and skills that are passed on from one generation to another". Foley's (1996) study of the "silent Indian" illustrates how the school serves as a site of cultural production of masculinity. Masculinity is therefore seen as a product of social structure embedded within social, cultural and educational systems. Social inequities are perpetuated as initial differences in cultural capital that become systematically encoded in educational credentials, human resources manuals, or the "silent culture," which together then funnel individuals (or rather reproduce individuals) into social class positions similar to those of their parents (Aschaffenburg \& Ineke, 1997).

The interconnection between mindscapes, language and linguistic codes discussed previously is one among many other connections drawn from identity and gender differences that sociologists identify. In fact, sociologists argue that the interconnection among race, gender and class produces a form of "intersectionality" that becomes important to consider in this analysis. The concept of "intersectionality" draws attention to the complex but reciprocal attachments and sometimes polarizing conflicts that confront both individuals and movements as they seek to navigate among the raced, gendered, and class-based dimensions of social and political life (Burgess-Proctor, 2006). This understanding of intersectionality affirms the view that categories of gender, race and sexuality, while operating "according to distinct logics, are interdependent and interrelated....as gender was never just about gender or a relation only between men and women" (Dill, 1988 - cited in Patil, 1993, p. 850).

By underscoring the interconnection between language and linguistic codes, "constructedness" of gender and the ways in which messages and meanings of socio-cultural categories of race, class, gender and ethnicity inform one another, theories of "performativity" and "intersectionality" become critical in understanding gender 
privilege. Performativity, however, asserts that no human being automatically becomes a man or a woman (Brickell, 2003). Instead, men and women are made or reproduced - that is, they are molded from birth to perform as boys or girls. For example, when a doctor pronounces that a newborn baby is a girl or boy, taken for granted affirmations and expected pronouncements activate numerous cultural, social and psychological processes. Inevitably, thereafter, the baby is incorporated into a "gendered" world of notions about what is expected of a girl or boy and how people will usually respond to her or him to fit into the categories associated with sex and gender that are used by society (Butler, 1993). Accordingly, in this case, the use of language (the utterance that it is a boy or girl) may be seen as proactive: something that creates reality and steers the gender discourse in a certain direction.

Perspectives of social constructionism, discourse analysis, semiotics of gender inequality, the sociology of social problems, and feminist viewpoints of intersectionality and performativity converge to form a theory that situates gendered privileges within the web of varieties of patriarchy. The symbolic forms that exist within this web of patriarchies are sometimes visible and other times invisible in the ways language is used, figurative messages are formulated, media messages are crafted, and metaphors are employed to represent inequality in patriarchal gendered structures. The argument of this study is summed up in Hunnicutt's (2009, p. 555) varieties of patriarchy:

"There are labyrinths of power dynamics (italics original). Privilege and rewards cannot be understood as a simple formula of 'oppressor' and 'oppressed'. Patriarchal systems must be envisioned as 'terrains of power' in which both men and women wield varying types and amounts of power".

For these reasons, we argue that symbolic patriarchy must be understood "holistically" rather than in terms of interlocking structures of domination. The task rests in the continuous quest to locate the labyrinths of power in the social landscapes and mindscapes of gendered privilege.

\section{Mindscapes and Semiotics of Gendered Privilege}

We have clarified how masculinity is (re)produced in society, explaining one of the ways inequalities and male dominance are perpetuated. We concluded "gendered privilege" is a mental construct developed and nurtured by patriarchal ideologies that favor masculinity over femininity in contexts such as paid labor. This culturally-installed male dominance can be explained further in other ways that focus on the conscious and unconscious mental processes that take place within people's minds by examining the symbols and metaphors that contribute to sustain inequalities, even in subtle ways, or reify masculinity and enforce gender privilege and its signification.

A project that focuses on mental processes, mindscapes or frames of gendered privilege opens up possibilities to discuss gendered spaces that cut across class, race, ethnicity, marital status, and sexual orientation. As mental frames, these mindscapes conjure up ideas about the imaginative and material worlds of gender and reflect the interconnectivity of phenomena in our age, past and present. Mindscapes also take up semiotics of gender shedding light to the signs, images, and metaphoric language that is intrinsic to the formation of the symbolic order of gender in our times.

Given the power of metaphors and the multiple meanings of gender and privilege possible in the semiotic genres, this analysis examines the related secondary question: How do signs, symbolic language, figurative or metaphoric structures and mindscapes of wider polity convey meanings of today's structures of privilege and rewards to create mindscapes of a gendered workforce? The semiotics of gender expose the symbolic gender spaces to understand unconscious constructions of male and female positions in society and the way we make meaning of deep unconscious motives in relationship to cultural biases that give rise to gender inequality.

\subsection{Semiotic Processes and Metaphors}

Theories of semiotic processes, including Lacan's (2006) concept of the psychoanalytic signifier, are critical in understanding the signs of gender, which include images, stories, poetry, and literature. The semiotic analysis proposed here, however, is not meant to substitute the other types of analysis research but to function as a complement to them. As stated previously, gender concepts develop out of unconscious biological feelings and social patterning that are for the most part invisible, natural, and irrevocable (Stewart, 1986).

Traditionally, the qualitative analysis of metaphoric structures has been the task of formalist literary criticism, which explicates the central meaning, values, symbols and ideologies in cultural artifacts propagated by industries of the media world by attending to the formal properties of imaginative literature texts - such as style, imagery, characterization, narrative structure, and point of view. The goal of such associations is the transfer of 
semiotic values that lead to actions that affirm existing beliefs or prompt an individual to act in a certain way. The semiotics of gender expose the metaphoric social structures of patriarchy found in works of literature, comedy, and films, and how the symbols derived permeate many social, political, religious, and educational institutions to the extent that they render gender privilege almost invisible, and relegate gender to be taken for granted.

In media advertising, for example, images of masculinity and the symbolisms in imagery that accrue within an advertising genre are presented to create associations between the product (men) and the associative quality that the cultural group values (virility). Textual analysis combines formalist analysis with critique of how cultural meanings convey specific ideologies of gender, race, class, sexuality, nation, and other ideological dimensions. Ideological textual analysis deploys a wide range of methods to explicate every dimension of our gendered lives to show how they fit into literary textual and symbolic systems.

From the 1960s on, however, literary-formalist textual analysis has been enhanced by methods derived from semiotics, a critical approach for investigating the creation of meaning not only in written languages but also in other, nonverbal codes, such as the visual and auditory languages of film, TV and music (Hall, 1997; Kellner, 1990; Semali, 2000). For example, an examination of the grand narratives of current times as representations of culture and how patriarchal metaphors are inscribed in them can shed light on the pervasive links of a century-old phenomenon of patriarchy (Woolf, 1979).

To feminist social thinkers and activists, Woolf's writings on segregation and professions for women (e.g. Three Guineas (1938, 2006), The Diary of Virginia Woolf (1979), and The Death of the Moth and Other Essays (1942) or Stephens' (2011) identification of gendered relations in A Midsummer Night's Dream, Cymbeline, and the Sonnets offer early and rich insights into the socioeconomic processes of occupational segregation, wage discrimination, imposition of separate spheres, social exclusion and trickle-down patriarchy (Orgel, 1996). The referenced authors of these classics acknowledge the power of symbolic, poetic or figurative language embedded in the grand narratives.

Momanyi (2007) analyzed poetical compositions to elucidate patriarchal structures and cultural aesthetics. Through the use of poetry, she reviewed how patriarchal ideologies of a given society are perpetuated. She showed how hegemonic forms of masculinity can be critically analyzed within historical periods. She pointed out that among the Waswahili of East Africa, there exist ideologies that justify men's superiority on the basis of cultural traditions (e.g., the exclusion of women from participating in certain customary rituals), religious ideologies, and sexual differences. In her analysis of poetry and other works, Momanyi identified Waswahili men as the cultural managers of the existing patriarchal symbolic order in which language, for example, is used to define sexuality as a binary opposition registering differences between men and women - these differences have been manipulated socially and culturally by male-constructed stereotypes of sexual difference.

Semiotic analysis can be connected with genre criticism (the study of conventions governing established types of cultural forms, such as soap operas) to reveal how the codes and forms of particular genres follow certain meanings. Situational comedies, for instance, classically follow a conflict/resolution model that demonstrates how to solve certain social problems by correct actions and values, and thus provide morality tales of proper and improper behavior. For example, a semiotic analysis of the 2001 film Vanilla Sky illustrates how Cameron Crowe's film presents a remake of a 1997 Spanish film, and how the use of celebrity stars Tom Cruise and Penelope Cruz, involved in a real-life romance, provides a spectacle involving modern icons of beauty, desire, sexuality, and power (Dines \& Humez, 1995, p. 4).

\subsection{Ideation of Gender Mindscapes}

To illustrate further the ideation of gender mindscapes, perhaps there is no other media that peddle images of masculinity more than films. For example, Table 1 shows that the 2013 top-grossing films were also flicks that explicitly reify masculinity and which also are big money earners at the box office. Thus, according to Forbes Magazine, "the film [Iron Man 3] has been the top grosser of the summer, bringing in $\$ 1.2$ billion at the global box office...It keeps the Marvel money train moving..." (Hughes, 2013). There is "a trend toward defining 'superheroics' in strictly traditional masculine terms" (Baker \& Raney, 2007), and Iron Man 3, Man of Steel and Wolverine all represent images of the male superhero in which the protagonist demonstrates superhero characteristics through stereotypical masculine behavior. 
Table 1. "Masculinity" in top 20 grossing films in 2013 (USA)

\begin{tabular}{lllllll}
\hline \# & & & & IMDB & & \\
\hline 1 & Title & Year & Type & Rating & \#Ratings & Date \\
2 & Iron Man 3 & 2013 & Feature & 7.6 & 218,699 & 3 months ago \\
3 & Despicable Me 2 & 2013 & Feature & 7.8 & 62,252 & 1 month ago \\
4 & Man of Steel & 2013 & Feature & 7.7 & 213,875 & 1 month ago \\
5 & Monsters University & 2013 & Feature & 7.7 & 48,600 & 1 month ago \\
6 & Fast \& Furious 6 & 2013 & Feature & 7.3 & 120,871 & 2 months ago \\
7 & Oz the Great and Powerful & 2013 & Feature & 6.5 & 101,712 & 5 months ago \\
8 & Star Trek Into Darkness & 2013 & Feature & 8.1 & 136,788 & 2 months ago \\
9 & World War Z & 2013 & Feature & 7.2 & 105,845 & 1 month ago \\
10 & The Croods & 2013 & Feature & 7.3 & 36,106 & 4 months ago \\
11 & The Heat & 2013 & Feature & 7 & 22,687 & 1 month ago \\
12 & The Great Gatsby & 2013 & Feature & 7.4 & 92,890 & 3 months ago \\
13 & Identity Thief & 2013 & Feature & 5.6 & 44,176 & 6 months ago \\
14 & Grown Ups 2 & 2013 & Feature & 5.1 & 16,250 & 2 weeks ago \\
15 & G.I. Joe: Retaliation & 2013 & Feature & 5.9 & 71,396 & 4 months ago \\
16 & The Conjuring & 2013 & Feature & 7.8 & 41,830 & 1 week ago \\
17 & Now You See Me & 2013 & Feature & 7.4 & 72,029 & 2 months ago \\
18 & The Wolverine & 2013 & Feature & 7.1 & 63,461 & 1 week ago \\
19 & The Hangover Part III & 2013 & Feature & 6.1 & 61,873 & 2 months ago \\
20 & Epic & 2013 & Feature & 6.6 & 18,969 & 2 months ago \\
\hline & Olympus Has Fallen & 2013 & Feature & 6.5 & 75,358 & 4 months ago \\
\hline
\end{tabular}

Source: Forbes Magazine:

http://www.forbes.com/sites/dorothypomerantz/2013/08/07/from-the-purge-to-r-i-p-d-the-summer-in-hits-and-m isses/ (Accessed 23 August, 2013).

Equally, $O z$ the Great and Powerful represents stereotypes of women in which Michelle Williams plays the damsel in distress as Annie/Glinda the Good Witch, and both Rachel Weisz and Mila Kunis represent the "la femme fatale" (i.e., a seductive woman who lures men into dangerous or compromising situations) stereotype as wicked sister witches Theodora and Evanora. In this film, James Franco plays Oz the Great and Powerful, who saves the Land of $\mathrm{Oz}$ from wicked witches.

Perhaps this perspective may also be illustrated by looking at some works of literature. (See Table 2) These examples show that stereotyping of women in popular works of literature are prevalent and continue to drive gendered mindscapes. The point is cogently made if we consider "masculinity" as if it were a brand name. A brand is a system of signs and symbols that engages the consumer in an imaginary/symbolic process that contributes tangible value to a product offering. Every society has its own revered symbols that have been manufactured for many years to reify masculinity as superheroes in visually projected pictures, figurines, and marketable products (e.g., Incredible Hulk costumes) that symbolize male superiority or valor. 
Table 2. Stereotypes in works of literature

\begin{tabular}{lll}
\hline Title & Author & Stereotype \\
\hline The Crucible & Arthur Miller & $\begin{array}{l}\text { Women as villains and/or sterile } \\
\text { wives (puritanical) (Schissel, 1994) } \\
\text { The Scarlet Letter }\end{array}$ \\
Women's fulfillment through \\
Susana San Juan & Juan Rulfo & $\begin{array}{l}\text { Wolf-sacrifice (Herbert, 1988) } \\
\text { Women as subject and object of } \\
\text { desire (de Valdés, 1994) }\end{array}$ \\
La Muerte de Artemio Cruz & Carlos Fuentes & $\begin{array}{l}\text { The subversion of social codes for } \\
\text { women (Gyurko, 1974) }\end{array}$ \\
\hline
\end{tabular}

Semiotic symbols - visual, audio, verbal signs, imaginary or artificial—enhance our understanding of the pervasive nature of metaphoric structures and the gains for studying such structures rather than patriarchal gender. In this analysis, the widespread phenomenon of male-dominated (gendered) categories, in the workplace and outside, reveals how widespread patriarchal mental frames, whether visible or invisible, have dominated throughout history of societies and their deep seeded psyche of mindscapes that pervade the symbolisms of gendered patriarchal privilege and its influence on the social order.

\section{How Socio-Cultural Systems of Inequality Explain the Dynamics of Privilege in Appalachia}

Next, we turn to inequality as an explanatory dynamic of gendered privilege and rewards in Appalachia. The U. S. Appalachian region refers to the land along the Appalachian mountain range along the eastern part of the United States. This region spans thirteen U.S. states: New York, Ohio, Pennsylvania, Maryland, West Virginia, Virginia, Kentucky, Tennessee, North Carolina, South Carolina, Georgia, Alabama and Mississippi. Appalachia was chosen for its diverse, historically agrarian and religious mountainous regions that traditionally value gendered division of labor. "Typical patriarchal families were agrarian or artisanal and they functioned as family economies, often productive units" (Gordon \& Hunter, 1998).

Research has identified numerous factors that contribute to the gender wage gap. A U.S. Labor Department study found that many of these factors relate to differences in choices and behaviors of women and men in balancing their work, personal, and family lives. These factors include, most notably, the occupations and industries in which they work, and their human capital development, work experience, career interruptions, and motherhood (U.S. Department of Labor, 2009). For example, in Idaho, pay differences along gender lines become stark among workers who have spent decades working for the state (see Figure 2). 


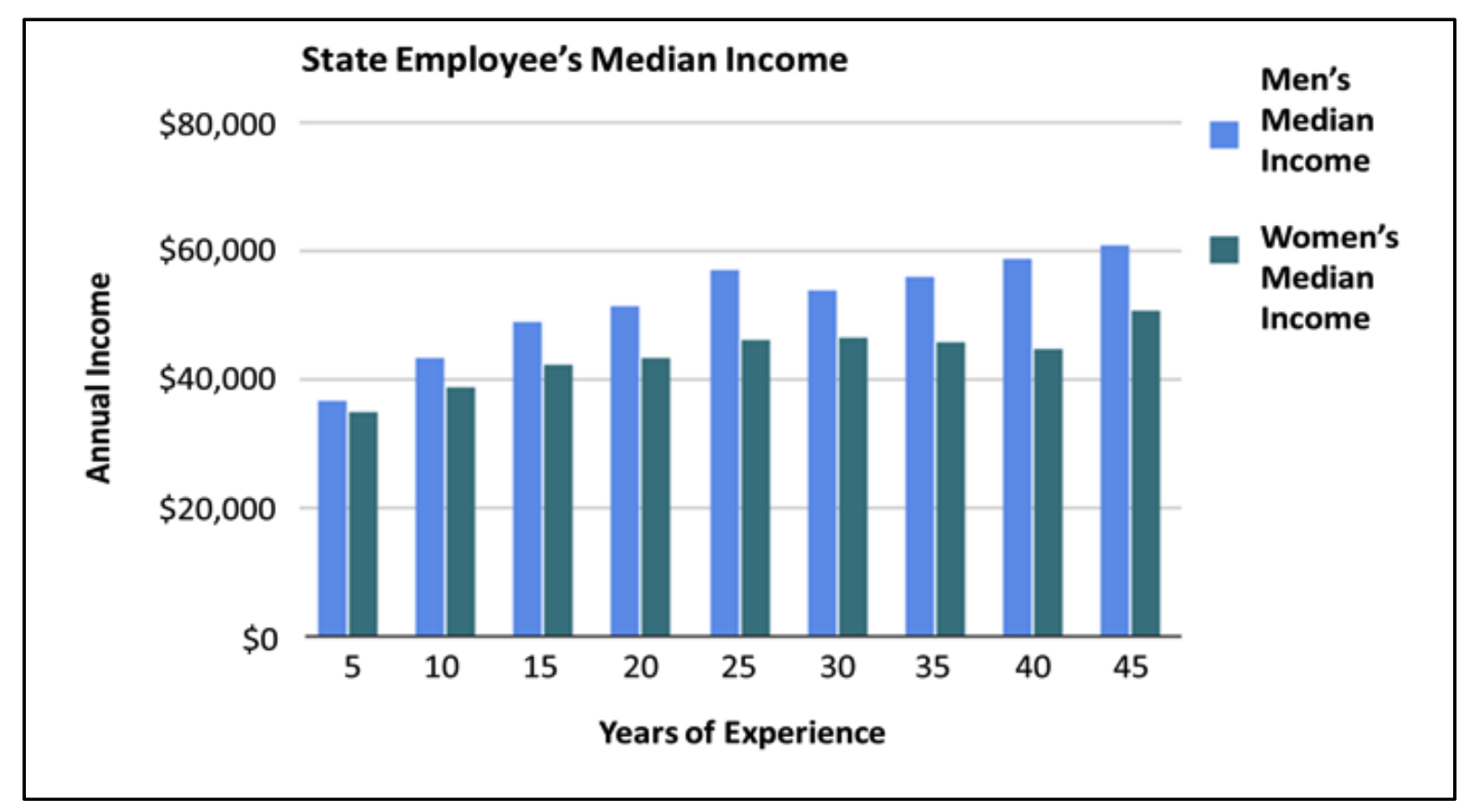

Figure 2. The gender pay gap in Idaho's state workforce: Why do women earn less? (Messick, 2013)

Source: Idaho state employee's median income: Office of the State Controller (Idaho; January 22, 2013).

A similar study conducted in Appalachia indicated disparities among professional women despite similar work experience (see Table 2). The results of salary differentials and regressions of earnings across occupations led Sigelman et al. (1982) to conclude that nearly all of the salary differentials could be explained away if one chooses sufficiently narrow occupational categories. Sigelman et al. (1982) further observed that this finding merely casts the problem in terms of why occupational distributions are so different between males and females.

Table 3. Male-Female salary differentials by category

\begin{tabular}{lcllll}
\hline & Male & Female & Difference & \multicolumn{1}{c}{ Skill } & Residual \\
\hline \multirow{3}{*}{ Less Experience } & $(\$ 55,389)$ & $(\$ 48,169)$ & $(\$ 7,671)$ & $(\$ 6,118)$ & $(\$ 1,553)$ \\
& 10.7789 & 10.6971 & 0.0819 & $0.0644(79 \%)$ & $0.0175(21 \%)$ \\
More Experience & $(\$ 48,000)$ & $(\$ 44,226)$ & $(\$ 3,774)$ & $(\$ 2,968)$ & $(\$ 805)$ \\
& 11.0378 & 10.9178 & 0.1200 & $0.0548(46 \%)$ & $0.0652(54 \%)$ \\
Research & $(\$ 62,182)$ & $(\$ 55,149)$ & $(\$ 7,033)$ & $(\$ 3,210)$ & $(\$ 3,822)$ \\
& 11.0102 & 10.7865 & 0.2236 & $0.1369(61 \%)$ & $0.0867(39 \%)$ \\
Comprehensive & $(\$ 60,485)$ & $(\$ 48,362)$ & $(\$ 12,123)$ & $(\$ 7,408)$ & $(\$ 4,715)$ \\
& 10.7835 & 10.6872 & 0.0963 & $0.0805(83 \%)$ & $0.0157(17 \%)$ \\
& $(\$ 48,218)$ & $(\$ 43,790)$ & $(\$ 4,428)$ & $(\$ 3,688)$ & $(\$ 740)$ \\
\hline
\end{tabular}

Source: Sigelman et al. (1982).

As is commonplace in the entire country, the workplace has been identified as fertile ground for multiple gendered inequalities - it is troubling to know that this phenomenon persists years after the passing of the Civil Rights legislation. In 1963, the Equal Pay Act was passed, requiring equal wages for women and men doing equal work. It was the first federal law to prohibit sex discrimination. In the following year, 1964, the Federal Civil Rights Act was passed, including Title VII, which guaranteed equal opportunity in employment. Title VII not only helped with equal opportunity and sex discrimination cases but also sexual harassment. Also, the Civil Rights Act created the Equal Employment Opportunity Commission, which is charged with enforcing workplace 
equality.

To sum up the history of inequality as a dynamic of privilege, let's examine the facts outlined by the Appalachia Women's Fund (2012):

- In the 1970 s, weekly earnings for the average woman working full time was $62 \%$ of men's weekly earnings;

- In 2010, Women's earnings were an average of $81 \%$ compared to their male counterparts;

- Women are more likely to work in low-wage, "pink-collar" jobs (teaching, child care, nursing, cleaning, and waitressing);

- In 2009, a total of 916,000 women earned a Bachelor's degree compared to 685,000 men;

- 18 out of the 500 largest corporations in the U.S. are run by females as of 2012;

- Because of the wage gap, women lose $\$ 443,360$ in a 40-year period, and each woman would need to work 12 years longer to make up the difference;

- In the U.S. 50,000 women are trafficked each year. $600,000-800,000$ are trafficked internationally;

- $\quad 98 \%$ of trafficking victims are female;

- In 2011 , it was determined that women make $3 / 4$ of family purchasing decisions, so why do these inequalities persist: For every dollar a man earns -

○ White women earn 77 cents,

- African-American women earn 69 cents,

○ Latinas earn 60 cents

- Since 2001, the wage gap has only closed by about $1 \%$. At this rate, women will be caught up to men in 45 YEARS! (Appalachia Women's Fund, 2012)

Even though women in the U.S. are generally judged to be equal to men, in practice this principle of equality and the apparent inequalities that persist between the sexes demonstrate an enduring dominance of male privilege and the distribution of material rewards. Elsewhere, outside of the U.S., the cultural and political history, gendered divisions of labor, combined with legal and religious structures that disenfranchise women, have not supported career aspirations or rewards beyond home-making and motherhood for most women (Stern, 1998). Wood (2001) observes that U.S. society is known to construct inequality by assigning different values to various skin colors, genders, sexual orientations, and classes, a realization that individuals' personal and professional lives are contoured by whether they fit what U.S. culture arbitrarily designates as superior. This realization makes everyone keenly aware that sex, gender, race, sexual orientation, and class profoundly influence individuals' knowledge, experience, and possibilities (Wood, 2001).

\section{Conclusion}

In this paper we examined the social conditions under which mindscapes of gendered privilege thrive and the ways in which knowing, thinking, and being a woman in the workforce become possible in the $21^{\text {st }}$ century. This article draws attention to the symbols of patriarchy and the many variables that account for the differences in pay between the sexes. The analysis revealed that there are many reasons for the gender pay gap, some of which are ideological while others are a product of patriarchal social arrangements driven by hegemonic masculinity and reinforced by socio-cultural systems of inequality that cut across class, race, ethnicity, marital status and sexual orientation. The study concluded that the issue of gender pay gap is one among many gendered privileges found in patriarchal societies, including the U.S.

In sum, exploring the relationship between symbolic patriarchy and gendered privileges in Appalachia is especially useful for theory building because the concept of patriarchy evokes images of gender hierarchies, dominance, and power arrangements in a fatherless working environment. Symbolic patriarchy is increasingly becoming dominant in society and social institutions and permeates, complete with its attendant symbols and metaphors, the institutions of civil society both ideologically and even practically.

For these reasons, symbolic patriarchy must be examined further in the social conditions within which it operates and normatively manifests itself. The main objective must be to probe the gaps in the belief systems and raise questions about how power is gendered regardless of sex. The underlying assumption of this method of analysis is to direct attention to the varieties of patriarchy that retain gender as a central organizing feature, maintaining a hierarchical emphasis and allowing the discussion to focus on social systems and social arrangements that reinforce or permit domination. The "social" is the environment external to individuals. And so we continue to ask: how is the social shaped by gender and how can this point of view explain the discrepancies between men and women in the workplace in Appalachia? Clearly, this approach uncovers the explanatory strengths of symbolic patriarchy and lays the foundation for a more fully developed theory that explains disparities and 
mindscapes of privilege in the gendered workforce.

\section{References}

Anderson-Levitt, K. (2003). Local meanings, global schooling: Anthropology and world culture theory. New York: Palgrave Macmillan. http://dx.doi.org/10.1057/9781403980359

Appalachia Women's Fund. (2012). Washington, DC: Appalachia Women's Fund. Retrieved August 7, 2013, from http://www.appalachianwomensfund.org/news/press-room

Arulampalam, W., Booth, A. L., \& Bryan, M. L. (2007). Is there a glass ceiling over Europe? Exploring the gender pay gap across the wage distribution. Industrial and Labor Relations Review, 163-186.

Aschaffenburg, K., \& Maas. I. (1997). Cultural and educational careers: The dynamics of social reproduction. American Sociological Review, 62(4), 573-587. http://dx.doi.org/10.2307/2657427

Bacchi, C. L. (1999). Women, policy and politics: The construction of policy problems. London: Sage.

Baker, K., \& Raney, A. A. (2007). Equally super: Gender-role stereotyping of superheroes in children's animated programs. Mass Communication \& Society, 10(1), 25-41. http://dx.doi.org/10.1080/15205430709337003

Barrett, M., \& McIntosh, M. (1980). The 'family wage': Some problems for socialists and feminists. Capital \& Class, 4(2), 51-72. http://dx.doi.org/10.1177/030981688001100104

Bell, M. P., McLaughlin, M. E., \& Sequeira, J. M. (2002). Discrimination, harassment, and the glass ceiling: Women executives as change agents. Journal of Business Ethics, 37(1), 65-76. http://dx.doi.org/10.1023/A:1014730102063

Bhasin, K. (1993). What is patriarchy? New Delhi: Kali for Women.

Blau, F. D., \& Kahn, L. M. (2001). Understanding international differences in the gender pay gap. No. w8200. National Bureau of Economic Research.

Bourdieu, P. (1977). Cultural reproduction and social reproduction. In J. Karabel, \& A. H. Halsey (Eds.), Power and ideology in education (pp. 487-511). Baltimore: Brookes Publishing.

Brickell, C. (2003). Performativity or performance: Clarifications in the sociology of gender. New Zealand Sociology, 18(2), 158-178.

Bureau of Labor Statistics. (2010). Labor force projections to 2010: Steady growth and changing composition. Washington, D.C.: U.S. Department of Labor.

Burgess-Proctor, A. (2006). Intersections of Race, Class, Gender, and Crime Future Directions for Feminist Criminology. Feminist Criminology, 1(1), 27-47. http://dx.doi.org/10.1177/1557085105282899

Butler, J. (1993). Bodies that matter: On the discursive limits of "sex". New York: Routledge.

Butler, J. (1997). Gender is burning: Questions of appropriation and subversion. Cultural Politics, 381-395.

Butler, J. (1999). Gender trouble. New York: Routledge.

Chitnis, S. (1988). Feminism: Indian ethos and Indian convictions. In R. Ghadially (Ed.), Women in Indian Society: A Reader (pp. 3-19). Newbury Park, CA: Sage.

Chodorow, N. (1978). The reproduction of mothering: Psychoanalysis and the sociology of gender. Berkeley, CA: University of California Press.

Chodorow, N. (1989). Feminism and psychoanalytic theory. New Heaven, CT: Yale University Press.

Christensen, W. M., \& Ferree, M. M. (2008). Cowboy of the World? Gender discourse and the Iraq War debate. Qualitative Sociology, 31(3), 287-306. http://dx.doi.org/10.1007/s11133-008-9106-0

Connell, R. W., \& Messerschmidt, J. W. (2005). Hegemonic masculinity rethinking the concept. Gender \& Society, 19(6), 829-859. http://dx.doi.org/10.1177/0891243205278639

Covert, B. (2012). The Ambition Myth: Debunking a Common Excuse for the Gender Wage Gap. The Atlantic. Retrieved July 30, 2013, from http://www.theatlantic.com/business/archive/2012/12/the-ambition-myth-debunking-a-common-excuse-forthe-gender-wage-gap/265744/

De Valdés, M. E. (1994). Sexuality and Insanity in Rulfo's Susana San Juan. Revista Canadiense de Estudios Hispánicos, 491-501. 
Eisenstein, Z. R. (Ed.). (1979). Capitalist patriarchy and the case for socialist feminism. New York: Monthly Review Press.

Figes, E. (1978). Patriarchal attitudes: Women in society. London: Virago.

Firestone, S. (1972). The Dialectic of Sex. London: Paladin.

Foley, D. (1996). The silent Indian as a cultural production. The cultural production of the educated person, 79-91.

Foucault, M. (1980). Power/knowledge: Selected interviews and other writings, 1972-1977. New York: Random House Digital, Inc.

Fox-Genovese, E. (1992). Feminism without illusions: A critique of individualism. Chapel Hill: University of North Carolina Press.

Fugiero, M. (2009). Equal Pay Act of 1963. In J. O'Brien (Ed.), Encyclopedia of gender and society (Vol. 1). Sage. http://dx.doi.org/10.4135/9781412964517.n136

Gordon, L., \& Hunter, A. (1998). Not all male dominance is patriarchal. Radical History Review, 1998(71), 91-95. http://dx.doi.org/10.1215/01636545-1998-71-71

Greer, G. (2008). The female eunuch. Harper Perennial Modern Classics.

Gyurko, L. A. (1974). Women in Mexican Society: Fuentes' Portrayal of Oppression. Revista Hispánica Moderna, 38(4), 206-229.

Habermas, J. (1991). The structural transformation of the public sphere: An inquiry into a category of bourgeois society. Boston: MIT press.

Hall, S. (Ed.). (1997). Representation: Cultural representations and signifying practices (Vol. 2). London: Sage.

Hanmer, J. (1990). Men, power, and the exploitation of women. Women's Studies International Forum, 13(5), 443-456. http://dx.doi.org/10.1016/0277-5395(90)90096-G

Hartmann, H. (1976). Capitalism, patriarchy, and job segregation by sex. Signs, 1(3), 137-169. Retrieved from http://www.jstor.org/stable/3173001

Henry, F., \& Tator, C. (2002). Discourses of domination: Racial bias in the Canadian English. Toronto: University of Toronto Press.

Herbert Jr., T. W. (1988). Nathaniel Hawthorne, Una Hawthorne, and The Scarlet Letter: Interactive Selfhoods and the Cultural Construction of Gender. Publications of the Modern Language Association of America, 285-297. Retrieved from http://www.jstor.org/stable/462377

Hughes, M. (2013). Top 10 most profitable movies in 2013 (so far). Forbes Magazine. Retrieved from http://www.forbes.com/sites/markhughes/2013/08/20/top-10-most-profitable-movies-of-2013-so-far

Hunnicutt, G. (2009). Varieties of patriarchy and violence against women resurrecting 'Patriarchy' as a theoretical tool. Violence against women, 15(5), 553-573. http://dx.doi.org/10.1177/1077801208331246

Institute for Women's Policy Research. (2012). IWPR Database. Washington, DC: Institute for Women's Policy Research, 2012. Institute for Women's Policy Research.

International Labor Organization (ILO). (2012). Gender pay gap drops, but not for the right reasons: ILO's Global Wage Report 2012/13. Rome: International Labor Organization.

Jaggar, A., \& Rothenberg, P. (1983). Women's Realities, Women's Choices. New York: Oxford.

Johnson, A. (1997). Gender Knot: Unraveling our patriarchal legacy and privilege, power, and difference. Philadelphia: Temple University Press.

Johnson, A. (2001). The gender knot: Unraveling our patriarchal legacy. Philadelphia: Temple University Press.

Kandiyoti, D. (1988). Bargaining with patriarchy. Gender \& Society, 2(3), 274-290. http://dx.doi.org/10.1177/089124388002003004

Kandiyoti, D. (1994). Identity and its discontents. In P. Williams, \& L. Chrisman (Eds.), Colonial Discourse and Post-colonial Theory (pp. 376-391). New York: Columbia University Press.

Kellner, D. (1990). Television and the Crisis of Democracy. Boulder, CO: Westview Press.

Khanna, S. (2012). Gender wage discrimination in India: Glass ceiling or sticky floor? Centre for Development Economics (CDE) Working Paper 214. http://dx.doi.org/10.2139/ssrn.2115074 
Knoppers, A. (1993). A Critical Theory of Gender Relations. In S. van Leeuwen (Ed.), After Eden: Facing the Challenge of Gender Reconciliation (pp. 225-233). Grand Rapids, MI: Eerdmans.

Labor Department Statistics Bureau (BLS) (Ed.). (2011). Highlights of Women's Earnings. Collingdale, PA: Diane Publishing Co.

Lacan, J., Fink, B. T., Fink, H. C., \& Grigg, R. C. (2006). Écrits: The first complete edition in English. New York: WW Norton \& Co.

Lerner, G. (1986). The Creation of Patriarchy (Vol. 1). Oxford: Oxford University Press.

Levine, D. (2012). Walmart gender discrimination lawsuit allowed to proceed, Judge Says. Reuters. Retrieved from http://www.huffingtonpost.com/2012/09/22/walmart-gender-discrimination_n_1905204.html

Lorber, J. (1994). Paradoxes of gender. New Heaven: Yale University Press.

Maltz, D. N., \& Borker, R. A. (1982). A cultural approach to male-female miscommunication. In D. N. Maltz, \& R. A. Borker (Eds.), Language and Social Identity (pp. 196-216). Cambridge: Cambridge University Press.

Mandell, N. (Ed.). (1995). Feminist Issues: Race, Class and Sexuality. Toronto: Prentice Hall.

Martin, J. (1994). The organization of exclusion: Institutionalization of sex inequality, gendered faculty jobs and gendered knowledge in organizational theory and research. Organization, 1(2), 401-431. http://dx.doi.org/10.1177/135050849412011

McLaren, P. (1999). Schooling as a ritual performance: Towards a political economy of educational symbols and gestures. Lanham, MD: Rowman \& Littlefield.

Mead, G. H. (1934). Mind, Self and Society. Chicago: University of Chicago Press.

Meade T., \& Haag, P. (1998). Persistent Patriarchy: Ghost or Reality? Radical History Review, 71, 91-95. http://dx.doi.org/10.1215/01636545-1998-71-91

Messick, M. (2013). The Gender Pay Gap in Idaho's State Workforce: Why Do Women Earn Less? Boise, ID: Boise State Public Radio.

Millett, K. (1977). Sexual Politics. London: Virago.

Mitchell, J. (1971). Women's estate. Pantheon, 110, 101-110.

Momanyi, C. (2007). Patriarchal Symbolic Order: The Syllables of Power as Accentuated in Waswahili Poetry. The Journal of Pan African Studies, 1(8), 1-10. Retrieved from http://www.jpanafrican.com/docs/vol1no8/SyllablesOfPowerAccenturatedInWaswahili_JPASvol1no8.pdf

Neumark, D. (1993). Sex discrimination and Women's labor market interruptions. National Bureau of Economic Research (NBER) Working Paper No. 4260. Chicago: University of Chicago Press. Retrieved from http://www.nber.org/papers/w4260.pdf

Orgel, S. (1996). Impersonations: The Performance of Gender in Shakespeare's England. Cambridge, England: Cambridge University Press.

Patil, V. (2013). From patriarchy to intersectionality: A transnational feminist assessment of how far we've really come. Signs, 38(4), 847-867. http://dx.doi.org/10.1086/669560

Phelps, E. S., \& Lehman, E. C. (Eds.). (2005). Forensic Accounting. San Francisco: West's Encyclopedia of American Law, Gale.

Pomerantz, D. (2013). From “The purge" to "R.I.P.D.”: The Summer in Hits and Misses. Forbes Magazine. Retrieved from http://www.forbes.com/sites/dorothypomerantz/2013/08/07/from-the-purge-to-r-i-p-d-the-summer-in-hits-a nd-misses/

Ray, S. (2006). Understanding patriarchy. Foundation course on Human Rights, Gender \& Environment, University of Delhi. Mainstream, Vol. XLVIII, 18.

Schaefer, R. T., (Ed.). (2008). Privilege. Encyclopedia of race, ethnicity, and society (Vol. 1). Sage.

Schissel, W. (1994). Re (dis) covering the Witches in Arthur Miller's The Crucible: A Feminist. Modern Drama, 37(3), 461-473. http://dx.doi.org/10.1353/mdr.1994.0040

Seidman, G. W. (1999). Gendered citizenship. South Africa's Democratic Transition and the Construction of a Gendered State. Gender \& Society, 13(3), 287-307. http://dx.doi.org/10.1177/089124399013003002 
Semali, L. M. (2000). Literacy in multimedia America. New York: Flamer.

Sigelman, L. H., Milward, B., \& J. M. Shepard. (1982). The Salary Differential between Male and Female Administrators: Equal Pay for Equal Work? Academy of Management Journal, 25(3), 664-671. http://dx.doi.org/10.2307/256088

Smiley, M. (2004). Democratic citizenship v. patriarchy: A feminist perspective on Rawls. Fordham L. Rev., 72, 1599. Retrieved from http://ir.lawnet.fordham.edu/flr/vol72/iss5/11

Stephens, P. (2011). Master Mistress: Gendered relations in a Midsummer Night are Dream, Cymbeline, and the Sonnets. In S. Bennett, \& C. Carson (Eds.), Shakespeare beyond English (pp. 29-317). Cambridge: Cambridge University Press.

Stern, S. J. (1998). What Comes After Patriarchy? Reflections from Mexico. Radical History Review, 1998(71), 55-62. http://dx.doi.org/10.1215/01636545-1998-71-55

Stewart, D. W. (1986). Lacan's linguistic unconscious and the language of desire. Psychoanalytic Review, 73(1), $17-29$. Retrieved

from http://ezaccess.libraries.psu.edu/login?url=http://search.proquest.com.ezaccess.libraries.psu.edu/docview/85 474351? accountid $=13158$

Sunderland, J. (2004). Gendered discourses. London: Palgrave Macmillan. http://dx.doi.org/10.1057/9780230505582

Tannen, D. (1994). Gender and discourse. New York: Oxford University Press.

Thompson, D. (2013). The Biggest Myth about the Gender Wage Gap. The Atlantic. Retrieved May 30, 2013, from

http://www.theatlantic.com/business/archive/2013/05/the-biggest-myth-about-the-gender-wage-gap/276367

U.S. Department of Labor (DOL). (2011). Women's employment during the recovery. Washington, D.C.: U.S. Department of Labor.

U.S. Department of Labor. (2009). An analysis of reasons for the disparity in wages between men and women. Washington, DC: CONSAD Research Corporation.

U.S. Department of Professional Employees (DPE). (2011). Professional Women: A Gendered Look at Occupational Obstacles and Opportunities. Washington, D.C.: U.S. Department of Professional Employees.

Valian, V. (1999). Why so slow? The advancement of women. Boston: The MIT Press.

Walby, S. (1986). Patriarchy at work: Patriarchal and capitalist relations in employment. Polity Press.

Walby, S. (2002). Towards a Theory of Patriarchy, in The Polity Reader in Gender studies. London: Blackwell Publishers.

West, C., \& Zimmerman, D. H. (1987). Doing gender. Gender \& Society, 1(2), 125-151. http://dx.doi.org/10.1177/0891243287001002002

Wodak, R., Meyer, M., Titscher, S., \& Vetter, E. (2000). Methods of text and discourse analysis: In search of meaning. Sage Publications Limited.

Wood, J. T. (2001). Gendered lives: Communication, gender, and culture. Wadsworth: Belmont, California.

Wood, J. T., \& Lenze, L. F. (1991). Gender and the development of self: Inclusive pedagogy in interpersonal communication. Women's Studies in Communication, 1-23.

Woolf, V. (1931). Professions for women. The death of the moth and other essays, 235-242.

Woolf, V. (1966). Three guineas, 1938. Reprint, San Diego: Harvest/HBJ.

Woolf, V. (1979). The diary of Virginia Woolf (Vol. 1). Mariner Books.

Woolf, V. (2006). Three guineas. New York: Harcourt.

World Bank. (2006). Labor force participation of women. Washington, DC: The World Bank Group. 


\section{Copyrights}

Copyright for this article is retained by the author(s), with first publication rights granted to the journal.

This is an open-access article distributed under the terms and conditions of the Creative Commons Attribution license (http://creativecommons.org/licenses/by/3.0/). 